\title{
The Impact of human capital on Company performance and the mediating effect of employee's satisfaction
}

\author{
${ }^{1}$ Muhammad Arsalan Shafique Awan, ${ }^{2}$ Naintara Sarfraz \\ ${ }^{1}$ Foundation University Islamabad \\ ${ }^{2}$ Foundation University Islamabad
}

\begin{abstract}
The principal of this research paper is to find the effect of human capital on performance of the firm with the mediating effect of employee's satisfaction with his job. The research type for this paper is quantitative and for the collection of data questionnaires were used.The sample size used for the paper was 200 and the target area was the telecom sector of Pakistanwhich included three leading companies in the telecom sector of Pakistan (i.e: Mobilink, Telenor and Ufone).The Results showed that Human capital investments has a strong relation with firm performance and employee's satisfaction mediates the process between both variables.

Key words: Human capital, performance, satisfaction, telecom, Pakistan
\end{abstract}

\section{Introduction:}

Human capital is stands among the most valuable and important assets of an organization. It helps the company to grow and achieve its goals more effectively and efficiently. So one major area of concern for a firm is to make investments in human capital. Human capital investments is basically a process of developing employees by providing them education or training or both. Education usually includes reimbursement of employees for formal education in universities and colleges. Education is used to develop employee's skills in areas like finance, accounting or production. Training however is conducted by supervisors working on the job with employees by teaching them specific functions and providing them knowledge to complete a certain task more effectively and efficiently.

Why it is important invest in Human capital?In the most basic terms all businesses must have capital in order to keep their firm going. Bank account, shares, assets and so forth are considered capital but among them all their also lies human capital. Humans utilize all the above mentioned capitals and carry out the operation of the firm so the importance of human capital investment can be seen from these factors that a firm that has more trained and skilled employees can perform better and produce more results than from a firm that has less human capital comparatively. In other words human capital is a major role player in performance of a firm.

The associationof human capital with performance is established on two theoretical basis. The first is the based on the resource viewand the second is the expectancy theory of motivationwhich represents three elements: (1) the valuelinked to the rewards,(2) the belief that the employee will be rewarded upon reaching a certain level of performanceand(3) the belief that the employee can achieve the certain level of performance in actual.

From an individual'sanglethe impact of human capital investments can be evaluated as raise in individual return. From an organizational angleimprovement in the returns from market and from a country'sangle, development in the economic.According to the study ofWorld Bank based on the evaluation of One ninety two countries in 1995 determined that general wealth is composedof physical capitalup to $16 \%, 20 \%$ of natural capital and the remaining $64 \%$ is imputed to human and social capital.

This study refers to the research that that tries to find a connection of human capital investments with the organizational performance. The query is that does the education, training and skills effect the company performance in any way. The concentration is upon consecutiveoccupationaltraining that happenwithin the companies and usually is rewarded by the employer. Companies that encourage high level of skills and abilities are likely to invest in Human capital which can help to understand the relation between Human capital investments and performance in a better way. A potential compelling vision, set of priorities held up with high quality of timely training and support should be carried out the firm to main high level of performance.

\section{Problem statement:}

The paper tends to examine the associationof the following variables.

1. Human capital.

2. Organizational performance and

3. the mediating effect of employee satisfaction between the two variables. 


\section{Originality:}

The paper tries to find the influence of Human capital on organizational performance. However many studies conducted before in the same area of research but this this study in unique as it tries to figure out the influence of human capital on organizational performance with the mediating effects of employees satisfaction towards his job.

\section{Applied Aspect:}

Performance is the key factor for success of every organization and every organization want to perform better than its competitors so it can keep its competitive edge and share of the market. Among other factors of performance Human capital investments is one factor that can have a outcome on the performance of both employees and the organization. Thus it can be crucial for managers and employers to invest in Human capital so they can achieve the level of performance they desire and keep up with the rapidly changes environment of the market.

\section{Objectives of the study:}

Following are the main objectives of the study.

- The study tries to find, how human capital investments effects organization performance.

- To study the level of effect of training of employees on firms performance.

- To determine if there is any relationship between two variables Human capital investments (independent variable) and firm performance (dependent variable).

- To find ways how to use human capital investments in a better way to achieve higher firm performance.

\section{Research questions:}

What is the influence of human capital on organizational performance?

Does employees satisfaction mediates the relation of human capital and organizational performance?

\section{Literature Review:}

Human capital is one of the most important factor that can contribute towards economic growth of a country. The contribution of an organization in its human capital can greatly benefit the firm and the individuals working in that firm. It helps in development of employees to be more productive which help the firm to perform better.

Human capital presents the image of the background knowledge of individuals grouped in theorganizationscomposite ability to disclose the optimum solution from its distinct employees(Bontis; 1999\&2001). The sum of employee's skill, abilities, experience and knowledge is known as Human Capital (Malone and Edvinsson; pp. 34-5, 1997).

The homogeneity between human capital and miscellaneous developed variables can be followed back to many courses of research, including organizational learning by Bontis in 2002,the economic human capital theory by Schultz in 1961\&Ducharme in 1998, the resource groundconcept of the organizationby Barney in 1991 and lately the knowledge ground concept of the organizationbyGrantin and Spender 1996.

It is exceptionally sanctioned factor that excessive competence and skillsare very important for the future success and security of an organization. It is commonly accepted that theeducation and training that apersonattains during a span of his professional career increase his abilities and potential to work, resolve problems and carry out innovation sohuman capital actuate the process of originating goods \& services together withcontemporary innovations required for the market. At present, the affiliationamongthe aspectsof human capital and economic evolvement is abundantly accepted. Despite theproductive valance of human capital, it is a matter of substantial interestfor researchers that what standard of human capital and to which extent is it essential to provide the organization with competitive advantage. (Starbuck, 1992 and Hassen, 1995).

The precedence of unconfined and distinct training is recognized by everyone. The leading augmentation directed by Paul Chapman in 1993in the speculation of training is the separation between two types of trainings, Specific trainingand General training. General training in particular escalates the prospective output which is for every firm in the market. Specific training is particular is associated with the firm and its relevant job. Usually it's because of the unique composition of the work and other organizations cant benefit much from it.

The ability of general training to enhance the prospective out of a worker comes with a risk that the worker might leave the organization after getting the training, this way the organization that initially provided the training bears a loss of training cost. So if the employer is providing its worker with general training either he should use a contract for the worker to work for him for specific years so that he gets the benefit of that training. 
The current market now a days faces increasingly rapid amount of changes in technology, systems and products. Usually most of the organization make investments in training of their employees because they believe that it will lead to higher performance and it will give them results (by Alliger, 1997 and Kozlowski, 2000). Anyhow there have been a number of debates on the affiliationof employees training onorganizational performance. Devanna and colleagues projecteda criterion in 1984 that articulatesthe relation of human resource management (HRM) and performance which describes that training of employees increase their productivity and performance which as a result increases firm performance.

In 1987 Guest developed a theoretical framework the emphasizes the effect of HRM policies on human resource and organization performance. The model developed by Guest is used as an systematicfoundation for examining the affiliation of the policies developed by HRM and organizational performance because of itsunobstructed and permissive usagefor experimentaltesting. He associated employees dedication as an important factor for achieving organizational goals, associating the employees with the performance of the organization.Human capital investment contribute towards the improved strategic integration, employee commitment, quality and flexibility. This way Human capital investments provide a way for high job performance, cost effectiveness, problem solving and lesser level of turn overs, absence and grievance.

Another model of theoretical framework which also interrelates the practices of human resource with the strategic planof the organization and the standards of outcome is the one disclosed by McMahan and Wright in 1992. They presented a total of six hypotheticalfigures from the fields of economics,financeand organizational theory and in which three presented the relationship of training and organizational performance.

Theoretical Framework and Hypothesis:

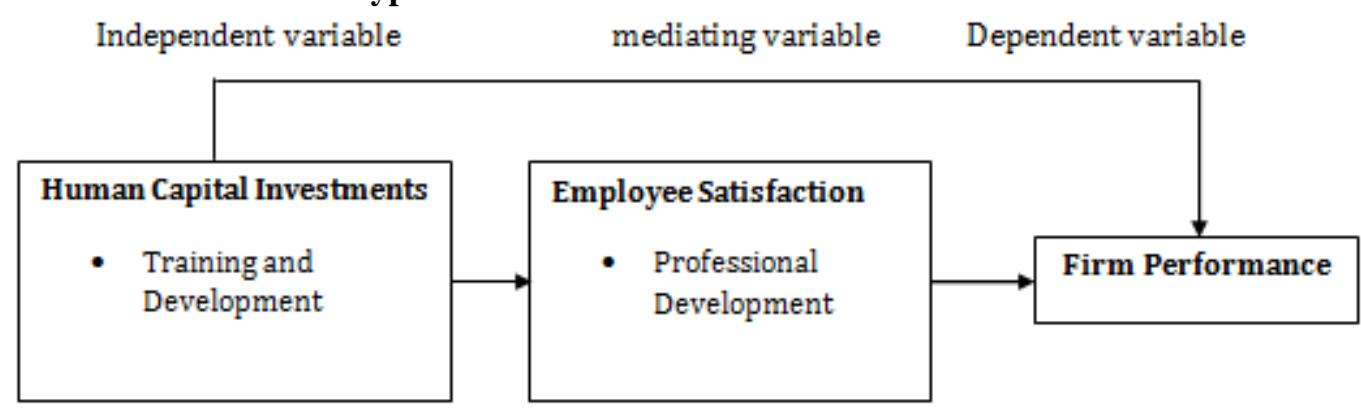

\section{Hypothesis:}

Following hypothesis have been generated in context with the theoretical framework.

H1: Human capital investments leads to high level of firm performance.

H2: Human capital investments leads to high level of employee satisfaction.

H3: High level of employee satisfaction leads to high level of firm performance.

H4: Employee Satisfaction mediates the relationship between Human capital investments and firm performance.

The present study involved three variables:

\section{Methodology:}

(1) The independent variables in the study is human capital investment.

(2) The dependent variables is performance of the firm.

(3) And Employee Satisfaction is serving the role of mediating variable between independent variable that is human capital investment and dependent variable that is form performance.

The research paper is carried out in the telecom sector of Pakistan and the universe for the paper consists of three companies in the telecom sector of Pakistan i.e. Ufone and Telenor and Mobilink. All the three companies hold a strong position in the telecom market and have a prominent amount of share in the market.

\section{Sampling Procedure:}

The research paper uses the technique of simple random sampling to collect the data from the targeted sector and companies of Pakistan. The sample include all the personals of the company as so to avoid biasness. A total of 200 responses were collected from the three companies and the result were calculated based on the responses gathered from these companies.

\section{Tools for data collection:}

The research paper used questionnaire survey approach to collect data for measuring all the variables and test the research hypotheses. For human capital a questionnaire with 5 points likert scale was used and it 
contained 10 questions. The dimension for human capital was Training and development. For employee's satisfaction a questionnaire also with 5 points likert scale was used and it also contained 10 questions. The dimension used for employee's satisfaction was professional development. Finally for the firm performance a questionnaire with 5 point likert scale was used and the total amount of question were limited to 5.

\section{Reliability of the Instruments:}

The reliability of the variables was calculated using Cronbach's alpha test and the results are mentioned in the table below

\begin{tabular}{|c|c|c|}
\hline Variables & Cronbach's Alpha & No. of Items \\
\hline Employee's Training & .900 & 10 \\
\hline Job Satisfaction & .845 & 10 \\
\hline Firm Performance & .840 & 5 \\
\hline
\end{tabular}

\section{Demographics Profile of the Respondents:}

\begin{tabular}{|c|c|c|}
\hline Gender & Frequency & Percent \\
\hline Male & 132 & 66 \\
\hline Female & 68 & 34 \\
\hline Total & 200 & 100 \\
\hline
\end{tabular}

\section{Data Analysis:}

The data was analyzed by using Statistical Package software for Social Science (SPSS) and the method of linear regression was used to test the hypothesis and find out the results for the research paper.

The results for the analysis are mentioned below.

H1: Human capital investments leads to high level of firm performance.

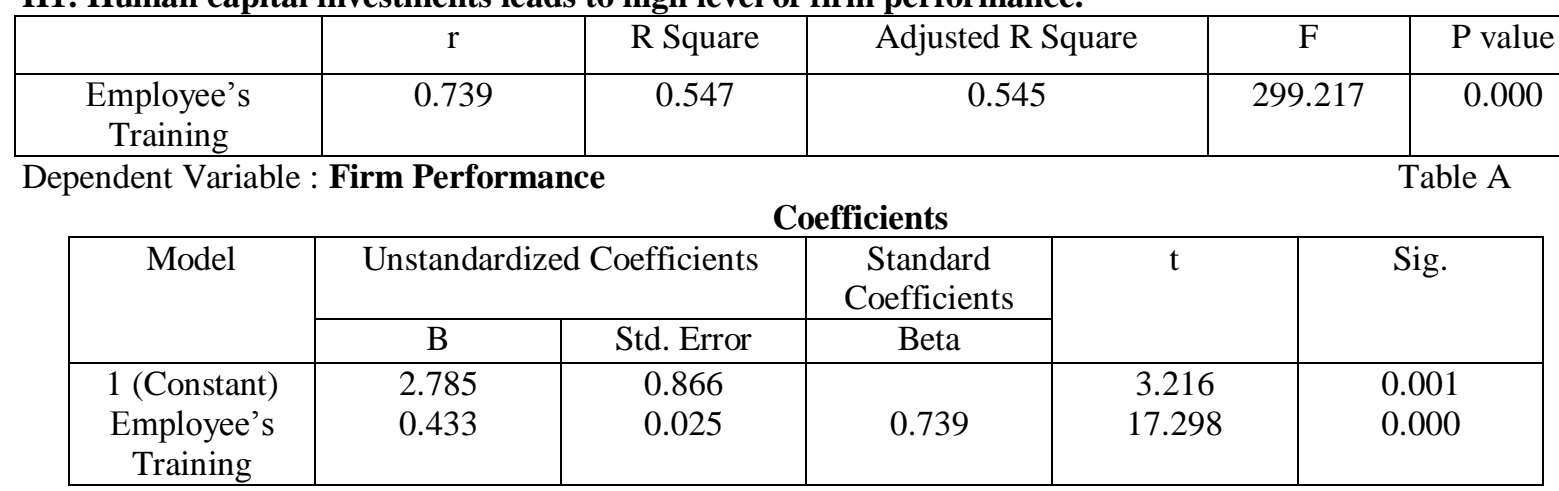

Dependent Variable : Firm Performance

In Table A, it can be seen from the results of analysis carried out in SPSS that $r=0.739$ which is higher than the regular value of 0.5 , which as a result shows that there is a strong relationship between the independent and dependent variables i.e. Employee's Training and Firm Performance. From the results54.7\% of firm performance is based on employee's training and remaining $45.3 \%$ is upon other factors. Therefore it can be concluded that employee's training highly effect the firm performance. The $\mathrm{P}$ value of the results is 0.000 which is less than 0.05 thus approving our first hypothesis.

H2: Human capital investments leads to high level of employee satisfaction.

\begin{tabular}{|c|c|c|c|c|c|}
\hline & $\mathrm{r}$ & R Square & Adjusted R Square & $\mathrm{F}$ & P value \\
\hline $\begin{array}{c}\text { Employee's } \\
\text { Training }\end{array}$ & 0.921 & 0.848 & 0.847 & $1.383 \mathrm{E} 3$ & 0.000 \\
\hline
\end{tabular}

Dependent Variable : Employee satisfaction

Table B 
The Impact of human capital on Company performance and the mediating effect of employee's

\begin{tabular}{|c|c|c|c|c|c|}
\hline \multicolumn{6}{|c|}{ Coefficients } \\
\hline \multirow{2}{*}{ Model } & Unstandardized Coefficients & $\begin{array}{c}\text { Standard } \\
\text { Coefficients }\end{array}$ & Sig. \\
\cline { 2 - 4 } & $\mathrm{B}$ & Std. Error & Beta & & \\
\hline 1 (Constant) & 5.149 & 0.793 & 0.921 & 37.185 & 0.000 \\
$\begin{array}{c}\text { Employee's } \\
\text { Training }\end{array}$ & 0.853 & 0.023 & 0.921 & \\
\hline
\end{tabular}

Dependent Variable : Employee satisfaction

In Table B, it can be seen from the results of analysis carried out in SPSS that $r=0.921$ which is higher than the regular value of 0.5 , which as a result shows that there is a very strong relationship between the independent and dependent variables i.e. Employee's Training and Employee's Satisfaction.From the results 84.8\% of employee's satisfaction is due to employee's training and remaining $15.2 \%$ is upon other factors. Therefore it can be concluded that employee's training highly effect employee's satisfaction. The $\mathrm{P}$ value of the results is 0.000 which is less than 0.05 thus approving our second hypothesis.

H3: High level of employee satisfaction leads to high level of firm performance.

\begin{tabular}{|c|c|c|c|c|c|}
\hline & $\mathrm{r}$ & R Square & Adjusted R Square & $\mathrm{F}$ & $\mathrm{P}$ value \\
\hline $\begin{array}{c}\text { Employee's } \\
\text { satisfaction }\end{array}$ & 0.797 & 0.635 & 0.633 & 431.173 & 0.000 \\
\hline
\end{tabular}

Dependent Variable : Firm Performance

Coefficients

\begin{tabular}{|c|c|c|c|c|c|}
\hline \multirow{2}{*}{ Model } & \multicolumn{2}{|c|}{ Unstandardized Coefficients } & $\begin{array}{c}\text { Standard } \\
\text { Coefficients }\end{array}$ & Sig. \\
\cline { 2 - 4 } & $\mathrm{B}$ & Std. Error & Beta & & \\
\hline 1 (Constant) & 0.306 & 0.841 & & 0.364 & 0.717 \\
Employee ‘s & 0.504 & 0.024 & 0.797 & 20.765 & 0.000 \\
Satisfaction & & & & & \\
\hline
\end{tabular}

Dependent Variable : Firm Performance

In Table $C$, it can be seen from the results of analysis carried out in SPSS that $r=0.797$ which is higher than the regular value of 0.5 , which as a result shows that there is a strong relationship between the independent and dependent variables i.e. employee's satisfaction and firm Performance. From the results $63.5 \%$ of firm performance is based on employee's training and remaining $36.5 \%$ is upon other factors. Therefore it can be concluded that employee's satisfaction highly effect the firm performance. The P value of the results is 0.000 which is less than 0.05 thus approving our third hypothesis.

H4: Employee Satisfaction mediates the relationship between Human capital investments and firm

\begin{tabular}{|c|c|c|c|c|c|}
\hline & $\mathrm{r}$ & R Square & Adjusted R Square & $\mathrm{F}$ & P value \\
\hline $\begin{array}{c}\text { Employee's } \\
\begin{array}{c}\text { Training } \\
\text { Employee's } \\
\text { satisfaction }\end{array}\end{array}$ & .797 & .635 & .632 & 214.920 & 0.000 \\
\hline
\end{tabular}

Dependent Variable : Firm Performance

Coefficients

\begin{tabular}{|c|c|c|c|c|c|}
\hline \multirow{2}{*}{ Model } & \multicolumn{2}{|c|}{ Unstandardized Coefficients } & $\begin{array}{c}\text { Standard } \\
\text { Coefficients }\end{array}$ & Sig. \\
\cline { 2 - 4 } & $\mathrm{B}$ & Std. Error & Beta & & \\
\hline 1 (Constant) & 2.785 & 0.866 & 0.739 & 17.298 & 0.001 \\
$\begin{array}{c}\text { Employee's } \\
\text { Training }\end{array}$ & 0.384 & 0.025 & 0.000 \\
\hline 2 (Constant) & 0.305 & 0.842 & 0.038 & 0.362 & 0.717 \\
$\begin{array}{c}\text { Employee's } \\
\text { Training }\end{array}$ & 0.022 & 0.062 & 0.762 & 7.729 & 0.701 \\
Employee's & 0.482 & 0.000 \\
Satisfaction & & & & & 0.000 \\
\hline
\end{tabular}

Dependent Variable : Firm Performance 
In Table D, it can be seen from the results of analysis carried out in SPSS that $r=0.797$ which is higher than the regular value of 0.5 , which as a result shows that there is a strong relationship of mediation of employee's satisfaction between the independent and dependent variables i.e. Employee's Training and Firm Performance. From the results $63.5 \%$ of firm performance is due to employee training and employee's satisfaction and remaining $36.5 \%$ is upon other factors. Therefore it can be concluded that employee's training highly effect the firm performance and employees satisfaction mediates the process between both variables. The $\mathrm{P}$ value of the results is 0.000 which is less than 0.05 thus approving our first hypothesis.

\section{Discussion:}

The aim of the study was to find the impact of human capital on firm performance with mediating effects of employees satisfaction in the telecom sector of Pakistan. After all the data analysis and calculation it is found that there is a strong relation of human capital to firm performance and also employees satisfaction has also a strong mediating role between both variables. Though the results didn't show a very strong relation between Human capital Investment and organization performance which might be due to the limitation of the research. Human capital investment contributes a lot when it comes to performance. It not only helps in enhancing employees skills and abilities but also increases their potential to work more efficiently, effectively and aggressively. The desire of employees to get promoted and get higher level of salaries leads to need of human capital investments in a way so that they can perform better and contribute more towards the firm and avail the opportunity to get promoted which in terms is related to employees satisfaction. Similar results are shown by the study which describe the effect of Human capital investments or employees training on firm performance. The research paper proves that there exists a link between human capital investments, employees satisfaction and firm performance. The more human capital investments made by the firm on its employees the more will be the employees satisfaction and the greater will be the firm performance as a result.

\section{Conclusion:}

This research paper has made its contributions in the field of human capital by targeting the telecom sector of Pakistan. The paper used quantitative data to conduct the research and test the various hypothesis. The results indicated the evidence that there is a significantly stronglink between human capital investment and organization performance. Furthermore the study indicates that the variable of employees satisfaction plays a significant role of a mediator between the two variables. The higher the human capital the better the firm performance therefore it is concluded as a result from the study that companies should strive to develop and train their employees to be able to perform better so it can attain its goals in an efficient way with a more rapid pace.

\section{Limitations:}

The paper studies the effects of human capital on organizational performance which is a broad topic. However due to shortage of budget the sample of the paper is kept low and only three companies from telecom sector were taken into account (i.e) Telenor, Ufone and Mobilink and the numbers of questionnaire were limited. Also the results from the research paper are limited to telecom sector of Pakistan only so the ability of generalization of this research paper is limited. It is recommended that a bigger sample size, with a more wider area of research (include more sectors of the market)for the next research to make the results more generalized.

\section{Recommendations:}

From the research paper it is recommended that organizations should pursue to invest in training and education of their employees which will help them not only maintain their core competences and also enhance their productivity and level of performance.

\section{References:}

[1] Hansson, B.; Johanson, U.; Leitner, K., H. The impact of human capital and human capital investments on company performance. Evidence from literature and European survey results.

[2] Acemoglu, D.; Pischke, J-S. Why do firms train?Theory and evidence. Quarterly Journal ofEconomics. Cambridge: MIT Press Journals,1998, Vol. 113, Issue 1, p. 79-119.

[3] Acemoglu, D.; Pischke, J-S. Certification of trainingand training outcomes. Cambridge: MIT -Massachusetts Institute of Technology, 1999b,p. 99-28 (Working paper).

[4] Ana-Maria, G. The Impact of Human Resources Practices uponSmall Companies Performances. Hyperion University, Calea Călăraşilor nr. 169, Bucureşti: Buletinul Universităţii Petrol - Gaze din PloieştiVol. LXNo. 2/2008, p 83 - 92.

[5] Seleim, A.; Ashour, A; and Bontis, N. Human capital and organizationalperformance: a study of Egyptiansoftware companies. Faculty of Commerce, Alexandria University:Management DecisionVol. 45 No. 4, 2007, p. 789-801.

[6] Jamal, W.; Saif, I. M. Impact of Human Capital Management on Organizational Performance. Department of Management Sciences, Foundation University Islamabad, Pakistan: European Journal of Economics, Finance and Administrative Sciences, ISSN 1450-2275 Issue 34 (2011) 
[7] Wan Yousaf, W. F.;Jatan, M.; Ibrahim, N., D.The interactive effect of Human capital, Structural capital and social capital on firm performance. Asian Academy of Management Journal, Vol. 9, No. 2, 1-18, July 2004

[8] Dicu, R.; Grosu, M. Optimizing Human capital between the motivation of employees and the performance required by the corporate responsibility. AlexandruIoan Cuza " University, Iasi, Romania. Luxembourg: Office for Official Publications of the European Communities, 2004. (Cedefop Reference series, 54)

[9] Ahangar, R., G. The relationship between intellectual capital and financial performance: An empirical investigation in an Iranian company. Department of Management and Economics. Islamic Azad University: African Journal of Business Management Vol. 5(1), pp. 88-95, 4 January, 2011.

[10] Clarke, M.; Seng, D.; Whiting, R., H. Intellectual Capital and Firm Performance in Australia. Department of Accountancy and Business Law. University of Otago :Working paper series no $12-2010$.

[11] Ahmadi, A., A; Ahmadi , F.; Shakeri, S. The survey of relationship between Intellectual capital(IC) and Organizational performance (OP) within the National Iranian South Oil Company. Islamic Azad University: Institute of Interdisciplinary Business Research 369, Spetember 2011, vol 3, no. 5 .

[12] Stephen, N.M, Nzuve; Ellyjoy G. Bundi . Human capital management practices and firm performance: A survey of commercial banks in Kenya. School of Business, University of Nairobi. 